\title{
Strengths Based Character Education for the Elderly: A Quasi-Experimental Study
}

\author{
Eduarda Rezende Freitas ${ }^{1, *}$ (D, Altemir José Gonçalves Barbosa ${ }^{2}$ (D, \& Carmem Beatriz Neufeld ${ }^{3}$ (1) \\ 'Universidade Católica de Brasília, Brasília, DF, Brasil \\ ${ }^{2}$ Universidade Federal de Juiz de Fora, Juiz de Fora, MG, Brasil \\ ${ }^{3}$ Universidade de São Paulo, São Paulo, SP, Brasil
}

\begin{abstract}
This study aimed to analyze an intervention on Strengths Based Character Education for the Elderly (Educafi) and its effects on the variables character strengths, psychological well-being, life satisfaction and depressive symptoms. Forty-one elderly people participated in the research, divided into three groups: experimental, active control and control. Participants answered the same questionnaires in three moments: pretest, post-test and follow up. Statistically significant results were obtained for depressive symptoms, but not for the positive constructs assessed. Elderly people who participated in Educafi decreased the levels of these symptoms from the pretest to the post-test. However, in the follow up they returned to the initial levels. The results are discussed and suggestions for Educafi and other positive interventions for the elderly are presented.
\end{abstract}

KEYWORDS: Positive Psychology, gerontology, positive intervention, psychological well-being

\section{Educação para o Caráter Baseada em Forças para Idosos: Um Estudo Quase-Experimental}

\begin{abstract}
RESUMO - O objetivo deste estudo foi analisar uma intervenção de Educação para o Caráter Baseada em Forças para Idosos (Educafi) e seus efeitos nas variáveis forças do caráter, bem-estar psicológico, satisfação com a vida e sintomas depressivos. Participaram da pesquisa 41 idosos distribuídos em três grupos: experimental, controle ativo e controle. Todos responderam aos mesmos questionários em três momentos, pré, pós e pós-teste tardio. Resultados estatisticamente significativos foram obtidos para os sintomas depressivos, mas não para os construtos positivos analisados. Idosos que participaram da Educafi diminuíram os níveis dessa sintomatologia do pré para o pós-teste, porém no pós-teste tardio retornaram aos patamares iniciais. Os resultados são discutidos e sugestões para essa e outras intervenções positivas para idosos são apresentadas.
\end{abstract}

PALAVRAS-CHAVES: Psicologia Positiva, gerontologia, intervenção positiva, bem-estar psicológico

Psychology, which historically is excessively turned towards pathologies, suffering and negative emotions, began to be more criticized in the 1990s for its "negativistic" emphasis, culminating in the proposition of Positive Psychology (PP) at the end of the $20^{\text {th }}$ century (Seligman $\&$ Csikszentmihalyi, 2000). Martin Seligman led this movement and appealed to psychologists to learn about the processes that contribute to human flourishing, directing efforts to the understanding of positive emotions, characteristics, and institutions (Niemiec, 2017). Therefore, PP proposes an expansion of the psychology focus on a positive direction.

Among the multiple constructs that have been the target of PP, this study emphasizes positive psychological characteristics, specifically the character strength (CS). Considered the "backbone" of PP, CS's are positive

*E-mail: eduardarezendefr@gmail.com

- Submetido: 31/03/2020; Aceito: 04/09/2020. 
personality traits that are manifested through thoughts, feelings and/or actions, therefore reflecting on the identity of each individual (Niemiec, 2017). Its use has been positively associated with well-being, personal fulfillment, life satisfaction (LS) and the reduction of depressive symptoms (Schutte \&Malouff, 2018).

CS's can be considered different routes to exhibit one or other virtue. Values in Action (VIA) lists 24 CS's subdivided into six virtues (Peterson \& Seligman, 2004). Courage virtue includes Bravery, Honesty, Persistence and Zest. Humanity embraces Love, Kindness and Social Intelligence. Justice virtue encompasses Teamwork, Fairness and Leadership. Wisdom and Knowledge covers the CS Open-mindedness, Creativity, Curiosity, Love of Learning and Perspective. Temperance virtue comprises Self-Regulation, Humility, Forgiveness and Prudence. Transcendence is composed of the CS Appreciation of Beauty and Excellence, Hope, Spirituality, Gratitude and Humor.

There is evidence that CS's promote well-being, improve relationships (Niemiec, 2017) and contribute to optimal development (Peterson \& Seligman, 2004) and positive aging (Hill \& Smith, 2015). Therefore, describing and promoting them in older adults is fundamental today and in the future, as population aging is a growing demographic phenomenon. In Brazil, the relative growth of the group of people over 60 is even higher than the general population (Instituto Brasileiro de Geografia e Estatística, 2018).

Even at a descriptive level, research on CS with samples exclusively composed by the elderly is still scarce. Nevertheless, there are studies that analyze these traits in old age (Baumann et al., 2020; Freitas, 2019) or present relations between $\mathrm{CS}$ and constructs that refer to this stage of the life span (Niemiec, 2017). As examples of the last investigation results, it is possible to mention the positive relationship identified between Love of Learning and healthy aging, between Perspective and successful aging and between Kindness, Prudence and Gratitude and longevity (Niemiec, 2017).

In a study (Freitas, 2019) that associated the 24 CS's to the variables gender, age, depressive symptoms, and psychological well-being (PWB) in a sample of elderly, no differences were found between men and women and only Self-Regulation was positively correlated with age. Regarding the depressive symptoms, negative correlations were obtained with five CS's: Teamwork; Curiosity; Forgiveness; Hope; and Humor. PWB was positively correlated with 11 of them (e.g., Humor, Curiosity, Forgiveness, Hope and Persistence).

Certainly, there are studies that analyze the entire set of CS's in different age groups samples, including the elderly. As an example, there is an investigation (Baumann et al.,
2020) that related CS and typical events of the transition to old age, such as retirement and widowhood, in a sample of adults (46 years old or older).

At an explanatory level, more specifically quasiexperiments and experiments to test strategies to promote CS in the elderly, scientific production is also limited. If, on one hand, meta-analyses (Bolier et al., 2013; Sin \& Lyubomirsky, 2009) confirm that positive interventions are effective to increase well-being and minimize depressive symptoms, on the other hand, they have corroborated that old age has been overlooked, because from the 51 investigations analyzed in one of them (Sin \& Lyubomirsky, 2009), only three were carried out with people 60 years old or over. In another meta-analysis (Bolier et al., 2013), from the 40 studies recovered, only two were implemented with older adults, and in only one of them the sample was composed exclusively by this age cohort. These results limit the analysis regarding the effectiveness of positive interventions with the elderly (Proyer et al., 2014), especially on the subject of the CS, as this construct was not considered in any of the five surveys with the elderly.

More recently, in a literature review of quasi-experimental studies on CS based interventions, there was also lack of research with samples composed by older adults (Ghielen et al., 2018). Studies that address this issue with people in old age, even if scarce, have been developed (Cuadra-Peralta et al., 2012; Flood \& Scharer, 2006; Ho et al., 2014; Jiménez et al., 2016; Kashaniyan \& Koolaee , 2015; Oliveira, 2010; Proyer et al., 2014; Ramírez et al., 2014; Ribeiro, 2011). They show that, in general, positive interventions, that is, activities whose goals are to cultivate positive feelings, behaviors and/or cognitions (Sin \& Lyubomirsky, 2009), can increase LS, PWB and subjective well-being and minimize depressive and anxious symptoms in the elderly.

If positive interventions with the elderly are one of the ways to flourish in old age, education is one of the most important ways to do so. New learning optimizes cognitive skills, strengthens the social support network for the older adults (Scoralick-Lempke \& Barbosa, 2012) and, in cases of education for character, promotes strengths, virtues, life skills and citizenship (Rich, 2009). There is empirical evidence that, for example, it is possible to accept and redefine age-related deficits, especially in advanced old age, by promoting CS, such as Gratitude and Forgiveness (Hill \& Smith, 2015).

Thus, positive interventions based on CS, more specifically character education, are strategies that can contribute substantially to positive aging. Aging positively concerns the achievement of LS, the development of functional coping strategies, the maintenance of physical capacity and the conservation of social support networks in 
old age (Killen \& Macaskill, 2020). In short terms, it can be said that positive aging preserves or promotes well-being (Hill \& Smith, 2015; Killen \& Macaskill, 2020).

Considering the growing number of elderly people and the imperative to adopt more active lifestyles (World Health Organization, 2015) to promote positive aging, the general objective of this study was to analyze a positive intervention, Strengths Based Character Education for the Elderly (Educafi) in the community's elderly. Specifically, the aim was to verify its effects on the CS, LS, PWB and depressive symptoms of the participants.

The following hypotheses were tested:
1. Elderly people who participated in Educafi would present CS scores slightly higher in the post-test and follow up when compared to those who did not undergo the intervention.

2. Educafi participants would have higher levels of PWB and LS in the post-test and would maintain these results in the follow up. The elderly in the control groups, on the other hand, would maintain the levels of these variables in the three moments of assessment.

3. Depressive symptom scores would decrease in the posttest only for the elderly who participated in Educafi. This result would be maintained in the follow up.

\section{METHOD}

\section{Participants}

Initially, 55 people aged 60 or over were recruited for this quasi-experiment. Age and preserved cognition were inclusion criteria. The initial exclusion criteria were not being literate and/or having an indication of depression. Such criteria were adopted to avoid bias, such as those resulting from the difficulty of understanding the items of the scales, allow the use of action plans based on reading and writing and control possible effects arising from pathological changes in mood. During the quasi-experiment, those who did not participate in any stage of the research (e.g., follow up) were also excluded, culminating in a final sample composed of 41 elderly (Figure 1) distributed in three groups: experimental $(n=15)$, active control $(n=15)$ or control $(\mathrm{n}=11)$.

\section{Instruments}

To assess inclusion and exclusion criteria, two instruments were used: the Mini-Mental State Examination (MMSE) (Brucki et al., 2003) and the Geriatric Depression Scale, reduced version (GDS-15) (Almeida \& Almeida, 1999). MMSE is a cognitive impairment screening instrument composed of 30 items that assess, among other domains, spatial and temporal orientation, immediate and evocation memory. For each item, the score is zero (error) or one (correct), with 30 being the maximum score. The cutoff points used were the ones suggested by Bertolucci et al. (1994), that is, a score of 18 or more for low and medium schooling and 26 or more for high schooling. These scores suggest cognitive preservation. The MMSE has a Cronbach's alpha of 0.71 (Lourenço et al., 2008). Other information regarding its psychometric properties (evidence of criterion validity and reliability, etc.) is available in Lourenço and Veras (2006) and Lourenço et al. (2008).

GDS-15 is a widely used scale to detect depressive symptoms in the elderly. It contains 15 questions answered with "yes" or "no" and scores ranging from zero (absent) to one (present). Those who score more than six points signalize an indicative of depression (Almeida \& Almeida, 1999) and, in this study, would be excluded. Cronbach's alpha is 0.81 . Information regarding internal consistency, validity and test-retest reliability can be obtained from Almeida and Almeida (1999).

Participants who met the inclusion and exclusion criteria in the previous step, answered three instruments. The VIAIS-120 was used to assess CS. It is a shortened version of the VIA Inventory of Strengths (VIA-IS). It contains 120 questions regarding $24 \mathrm{CS}$ 's (five items per CS). In each question, the score ranges from one ("very much unlike me") to five ("very much like me") and, therefore, the score for each CS varies between five and 25 points. So far, only the 240-item version of VIA-IS has had its psychometric properties investigated - adaptation, obtainment of evidence of validity, etc. - for the Brazilian context (Seibel et al., 2015). Nevertheless, the evidence of validity (concurrent and factorial) and the reliability estimate (internal consistency) of the VIA-IS-120 were analyzed in a sample of approximately five hundred thousand people (mostly adult) from all over the planet (Littman-Ovadia, 2015; Littman-Ovadia \&Lavy, 2015). However, no specific results are presented for Brazilians or the elderly. Cronbach's alphas of the VIAIS-120 (mean $\alpha=0.79$ ) are similar to those obtained for the VIA-IS (mean $\alpha=0.83$ ), and the mean correlation between the scales is 0.93 (Littman -Ovadia, 2015). 


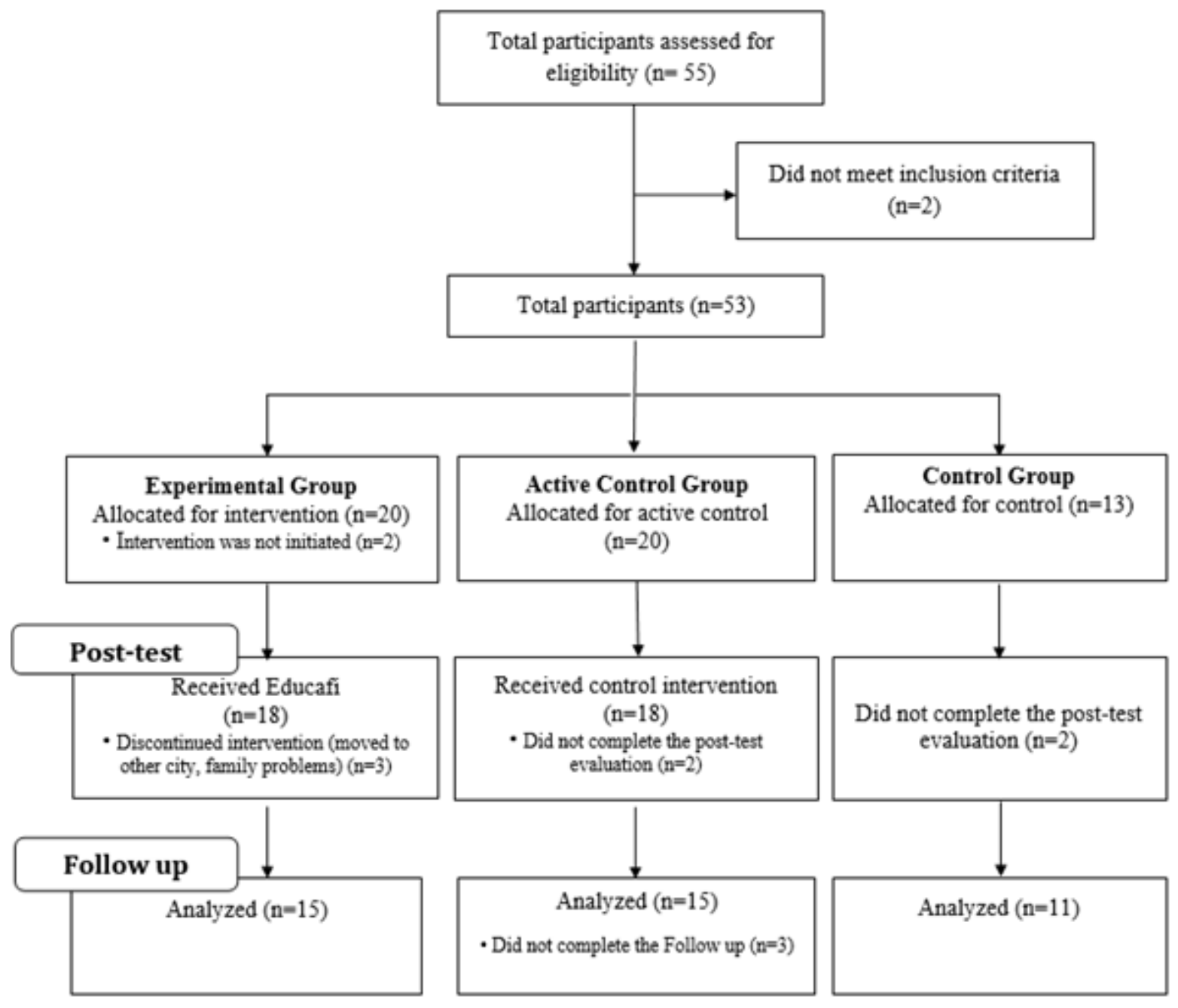

Figure 1. Flow of Participants in each Stage of the Study

In order to evaluate the PWB, the Philadelphia Geriatric Center Morale Scale (PGCMS) (Lawton, 1991) was used, a scale developed specifically for the elderly. It consists of 17 items, divided into three factors: Agitation (six items), Attitude Toward Own Aging (five items) and Lonely Dissatisfaction (six items). The total PWB is obtained from the sum of these factors, with a score ranging from zero to 17. For each item, there are dichotomous answer options, such as "yes" and "no". For higher scores to reflect a higher PWB, six items must be mirrored. The Brazilian version of the instrument, the PGCMS-Br, presented satisfactory psychometric properties, such as evidence of validity based on the internal structure and the relationship with other variables and good reliability estimate (Freitas et al., 2016a). Internal consistency was assessed using the KuderRichardson coefficient (kr-21), and adequate results were found for the total $(\mathrm{kr}-21=0.991)$ and for the three factors $(0.784 \leq 0.821)$ (Freitas et al., 2016a).

The Satisfaction with Life Scale - SWLS (Gouveia et al., 2005) was used to assess the participants' LS. It consists of five statements, and participants must choose from seven options, ranging from "strongly disagree" (value 1) to "strongly agree" (value 7). Thus, the total LS score varies between five and 35 and, so far, does not have a consensual cut-off point. The SWLS has validity evidence based on the internal structure - one dimension that explains $53 \%$ of the variance - and reliability estimates - Cronbach's alpha equals to 0.76 - for the elderly (Albuquerque et al., 2007).

\section{Procedure}

After approval by a Research Ethics Committee (14978913.8.0000.5147) and the fulfillment of the other ethical requirements (e.g., signing a free and informed consent term), Educafi began to be divulgated in different media and through the "snowball" strategy. Older adults interested in participating in Educafi should sign up in the institution where the group was held.

Elderly enrolled to participate in Educafi were contacted by the researchers and, once consenting to participate in the research, were individually assessed. Each assessment was carried out by a psychologist, who led Educafi, or a 
psychology student. Based on the inclusion and exclusion criteria, two elderly people were not included because they showed signs of cognitive decline and were referred to specialized services. Elderly people who met the criteria for participation in the study answered to the SWLS, PGCMS$\mathrm{Br}$ and VIA-IS-120 as pre-test. After performing these procedures, they became part of the experimental group. This group was submitted to Educafi (described in the next topic), held twice a week, with an approximate duration of 90 minutes each meeting.

The active control group was composed by older adults who signed up to participate in other group activities offered by the institution, but that did not have CS as focus. Thus, in this group there were elderly people who underwent different interventions, for example, Computer courses or Dance, but with analogous duration of Educafi, that is, group meetings held twice a week, with a total of 40 hours of intervention. The control group, on the other hand, did not undergo any intervention and was formed by elderly people from the community, recruited through the "snowball" strategy. This group did not participate in any group activities. It is noteworthy that the participants of the active control group and the control group responded to the same instruments used with the experimental group and in a similar time as pre-test.

After the end of Educafi, a post-test was carried out with all participants in the three groups. A follow up was also performed six months after the first post-test. At the end of this moment, the participants received a feedback, both orally and printed, on their $24 \mathrm{CS}$ 's and on the results of the other instruments. It should be noted that in the post-tests and follow up moments, VIA-IS-120, PGCMS-Br, SWLS and GDS-15 were applied.

\section{Intervention}

Educafi (Freitas et al., 2016b), the intervention tested in this study, aims to develop the CS proposed by Peterson and Seligman (2004), increase the participants' LS and
PWB and minimize depressive symptoms. Three theoretical contributions were adopted for its formulation. In addition to PP and Education for Character, it was based on CognitiveBehavioral Therapy (CBT) in Group (GCBT).

Educafi adopted the format of guidance and training groups, a modality that stands out in literature in GCBT (Neufeld et al., 2017). This group format uses psychoeducational strategies and practical activities so that, through guidance and training, participants achieve cognitive, behavioral and emotional changes.

At the first Educafi meeting, a contract was established and good rapport with the elderly and psychoeducation about PP started, emphasizing CS, and the cognitive model of CBT. The promotion of CS, properly speaking, started from the second meeting on. In this second meeting and the subsequent 23, the focus was on one CS on each day. Thus, Educafi lasted 26 meetings, making a total of 39 hours. More than two meetings per week were avoided so that the spacing between the days of group activity could be used by the older adults to carry out the action plans (tasks). At the final meeting, doubts were clarified, and a synthesis of the entire process was carried out. With the exception of the first and the last meeting, the following structure was adopted for each meeting: (1) Review of the Action Plan, (2) Brainstorming, (3) Deepening, (4) Feedback, (5) Summary and (6) Action Plan. (Freitas et al., 2016b).

\section{Data Analysis}

The data were analyzed using descriptive [mean (M) and standard deviation (SD)] and inferential statistics. In the latter case, after verifying normal distribution of the data, unidirectional variance analysis $(F)$ and factorial variance analysis were performed with time as a factor of repeated measures and group as an inter-participant factor $(F)$. In this last case, the Bonferroni test was used for multiple post hoc comparisons. The Phi Coefficient (Phi) was also used for nominal $2 \mathrm{X} 2$ contingency tables. A significance level of $5 \%$ was adopted.

\section{RESULTS}

Table 1 presents the demographic characteristics of each group. It is noteworthy that there was no significant difference between the elderly of the three groups regarding the variables age, number of years of schooling, gender, marital status and socioeconomic level.

Table 2 presents the averages and standard deviations of the 24 CS's per group and the analysis of factor variance. No significant results were obtained for the CS in the different groups and moments of evaluation.

In addition to CS, PWB, LS and depressive symptoms were also analyzed in all of the groups (experimental, active control and control) in the pre-test, post-test and follow up
(Table 3). There were statistically significant results only for depressive symptoms $(\mathrm{p}<0.05)$. The post hoc tests with Bonferroni revealed that the experimental group showed a declining trend in this symptom from the pre to the post-test, as the significance was limitrophe $(\mathrm{p}=0.052)$, and an increase in the post-test to the follow up $(\mathrm{p}<0.05)$. Therefore, depressive symptoms returned to the initial levels, that is, there was no statistically significant difference between pre-test and follow up. No significant differences were identified in the post hoc for the active control group and the control group. 
Table 1

Demographic Characteristics of the Participants by Groups.

\begin{tabular}{|c|c|c|c|c|}
\hline \multirow{2}{*}{ Variables } & \multicolumn{3}{|c|}{ Group } & \multirow{2}{*}{ IntergroupTests } \\
\hline & Experimental & Active Control & Control & \\
\hline Age & $M=67.93 ; D P=5.53$ & $M=67.27 ; D P=6.65$ & $M=72.82 ; D P=9.11$ & $\begin{array}{l}F=2.252 \\
p=0.119\end{array}$ \\
\hline Years of schooling & $M=10.07 ; D P=4.67$ & $M=11.27 ; D P=5.76$ & $M=8.55 ; D P=3.96$ & $\begin{aligned} F & =0.964 \\
p & =0.390\end{aligned}$ \\
\hline \multicolumn{4}{|l|}{ Gender } & \multirow{3}{*}{$\begin{array}{c}P h i=0.258 \\
p=0.256\end{array}$} \\
\hline Female & $n=15 ; 100 \%$ & $n=13 ; 86.7 \%$ & $n=9 ; 81.8 \%$ & \\
\hline Male & --- & $n=2 ; 13.3 \%$ & $n=2 ; 18.2 \%$ & \\
\hline \multicolumn{4}{|l|}{ Marital Status } & \multirow{5}{*}{$\begin{array}{c}P h i=0.424 \\
p=0.288\end{array}$} \\
\hline $\begin{array}{l}\text { Married or in a steady } \\
\text { relationship }\end{array}$ & $n=8 ; 53.3 \%$ & $n=6 ; 40 \%$ & $n=5 ; 45.5 \%$ & \\
\hline Divorced & $n=3 ; 20 \%$ & $n=2 ; 13.3 \%$ & $n=1 ; 9.1 \%$ & \\
\hline Widower & $n=4 ; 26.7 \%$ & $n=7 ; 46.7 \%$ & $n=3 ; 27.3 \%$ & \\
\hline Single & --- & -- & $n=2 ; 18.2 \%$ & \\
\hline \multicolumn{4}{|l|}{ Socioeconomic level } & \multirow{7}{*}{$\begin{array}{c}P h i=0.494 \\
p=0.439\end{array}$} \\
\hline A1 & $n=1 ; 6.7 \%$ & $n=1 ; 6.7 \%$ & -- & \\
\hline A2 & $n=2 ; 13.3 \%$ & $n=1 ; 6.7 \%$ & --- & \\
\hline $\mathrm{B} 1$ & $n=2 ; 13.3 \%$ & $n=4 ; 26.7 \%$ & $n=1 ; 9.1 \%$ & \\
\hline B2 & $n=3 ; 20.0 \%$ & $n=6 ; 40.0 \%$ & $n=6 ; 54.5 \%$ & \\
\hline $\mathrm{C} 1$ & $n=5 ; 33.3 \%$ & $n=2 ; 13.3 \%$ & $n=1 ; 9.1 \%$ & \\
\hline $\mathrm{C} 2$ & $n=2 ; 13.3 \%$ & $n=1 ; 6.7 \%$ & $n=3 ; 27.3 \%$ & \\
\hline
\end{tabular}

Table 2

Differences in Means and Standard Deviations in Pre-test, Post-test and Follow up of the Character Strengths by Group.

\begin{tabular}{|c|c|c|c|c|c|c|c|c|}
\hline \multirow{3}{*}{ Character strengths } & \multirow{3}{*}{ Measure } & \multicolumn{6}{|c|}{ Group } & \multirow{3}{*}{ ANOVA $^{\mathrm{a}}$} \\
\hline & & \multicolumn{2}{|c|}{ Experimental } & \multicolumn{2}{|c|}{ Active control } & \multicolumn{2}{|c|}{ Control } & \\
\hline & & M & SD & $\mathbf{M}$ & SD & M & SD & \\
\hline \multirow{3}{*}{ Open-mindedness } & Pre-test & 4.16 & 0.65 & 4.13 & 0.70 & 4.18 & 0.40 & \multirow{3}{*}{$\begin{array}{l}F=1.015 \\
p=0.405\end{array}$} \\
\hline & Post-test & 4.19 & 0.47 & 4.15 & 0.53 & 4.02 & 0.41 & \\
\hline & Follow up & 4.29 & 0.52 & 4.17 & 0.65 & 4.00 & 0.58 & \\
\hline \multirow{3}{*}{ Love } & Pre-test & 4.53 & 0.44 & 4.44 & 0.44 & 4.33 & 0.52 & \multirow{3}{*}{$\begin{array}{l}F=0.719 \\
p=0.582\end{array}$} \\
\hline & Post-test & 4.35 & 0.56 & 4.25 & 0.49 & 4.24 & 0.54 & \\
\hline & Follow up & 4.40 & 0.55 & 4.45 & 0.44 & 4.45 & 0.54 & \\
\hline \multirow{3}{*}{$\begin{array}{l}\text { Appreciation of Beauty } \\
\text { and Excellence }\end{array}$} & Pre-test & 4.35 & 0.59 & 4.37 & 0.53 & 4.25 & 0.52 & \multirow{3}{*}{$\begin{array}{l}F=1.204 \\
p=0.316\end{array}$} \\
\hline & Post-test & 4.35 & 0.53 & 4.27 & 0.55 & 4.18 & 0.56 & \\
\hline & Follow up & 4.29 & 0.55 & 4.21 & 0.62 & 4.38 & 0.55 & \\
\hline \multirow{3}{*}{ Honesty } & Pre-test & 4.67 & 0.33 & 4.63 & 0.45 & 4.75 & 0.30 & \multirow{3}{*}{$\begin{aligned} F & =0.260 \\
p & =0.903\end{aligned}$} \\
\hline & Post-test & 4.48 & 0.43 & 4.51 & 0.38 & 4.67 & 0.27 & \\
\hline & Follow up & 4.64 & 0.42 & 4.64 & 0.44 & 4.73 & 0.35 & \\
\hline \multirow{3}{*}{ Self-Regulation } & Pre-test & 3.75 & 0.78 & 4.01 & 0.65 & 4.07 & 0.74 & \multirow{3}{*}{$\begin{array}{l}F=0.792 \\
p=0.534\end{array}$} \\
\hline & Post-test & 3.88 & 0.73 & 3.87 & 0.80 & 3.96 & 0.91 & \\
\hline & Follow up & 4.05 & 0.62 & 3.99 & 0.78 & 4.05 & 0.57 & \\
\hline \multirow{3}{*}{ Kindness } & Pre-test & 4.68 & 0.43 & 4.49 & 0.52 & 4.75 & 0.32 & \multirow{3}{*}{$\begin{array}{l}F=0.327 \\
p=0.859\end{array}$} \\
\hline & Post-test & 4.68 & 0.40 & 4.51 & 0.42 & 4.69 & 0.27 & \\
\hline & Follow up & 4.72 & 0.41 & 4.55 & 0.50 & 4.64 & 0.36 & \\
\hline
\end{tabular}


Table 2

Cont.

\begin{tabular}{|c|c|c|c|c|c|c|c|c|}
\hline \multirow{3}{*}{ Character strengths } & \multirow{3}{*}{ Measure } & \multicolumn{6}{|c|}{ Group } & \multirow{3}{*}{ ANOVA $^{\mathrm{a}}$} \\
\hline & & \multicolumn{2}{|c|}{ Experimental } & \multicolumn{2}{|c|}{ Active control } & \multicolumn{2}{|c|}{ Control } & \\
\hline & & $\mathbf{M}$ & SD & $\mathbf{M}$ & SD & $\mathbf{M}$ & SD & \\
\hline \multirow{3}{*}{ Bravery } & Pre-test & 3.97 & 0.41 & 4.00 & 0.65 & 4.05 & 0.20 & \multirow{3}{*}{$\begin{array}{l}F=0.780 \\
p=0.542\end{array}$} \\
\hline & Post-test & 4.05 & 0.47 & 3.96 & 0.52 & 4.02 & 0.66 & \\
\hline & Follow up & 4.16 & 0.60 & 3.91 & 0.71 & 4.22 & 0.62 & \\
\hline \multirow{3}{*}{ Teamwork } & Pre-test & 4.32 & 0.37 & 4.08 & 0.57 & 4.13 & 0.56 & \multirow{3}{*}{$\begin{array}{l}F=0.535 \\
p=0.711\end{array}$} \\
\hline & Post-test & 4.13 & 0.54 & 4.07 & 0.54 & 4.09 & 0.44 & \\
\hline & Follow up & 4.27 & 0.52 & 4.21 & 0.46 & 4.31 & 0.55 & \\
\hline \multirow{3}{*}{ Creativity } & Pre-test & 3.96 & 0.66 & 3.92 & 0.67 & 4.02 & 0.64 & \multirow{3}{*}{$\begin{array}{l}F=1.100 \\
p=0.363\end{array}$} \\
\hline & Post-test & 4.12 & 0.68 & 3.99 & 0.61 & 3.87 & 0.66 & \\
\hline & Follow up & 3.99 & 0.88 & 4.05 & 0.70 & 4.20 & 0.61 & \\
\hline \multirow{3}{*}{ Curiosity } & Pre-test & 4.28 & 0.51 & 4.07 & 0.67 & 4.04 & 0.59 & \multirow{3}{*}{$\begin{array}{l}F=0.915 \\
p=0.446\end{array}$} \\
\hline & Post-test & 4.40 & 0.38 & 4.05 & 0.67 & 4.15 & 0.66 & \\
\hline & Follow up & 4.09 & 0.96 & 4.07 & 0.75 & 4.11 & 0.72 & \\
\hline \multirow{3}{*}{ Hope } & Pre-test & 4.36 & 0.45 & 4.28 & 0.58 & 4.51 & 0.43 & \multirow{3}{*}{$\begin{array}{l}F=0.063 \\
p=0.992\end{array}$} \\
\hline & Post-test & 4.33 & 0.46 & 4.27 & 0.64 & 4.49 & 0.55 & \\
\hline & Follow up & 4.45 & 0.47 & 4.32 & 0.61 & 4.55 & 0.40 & \\
\hline \multirow{3}{*}{ Spirituality } & Pre-test & 4.71 & 0.32 & 4.67 & 0.44 & 4.71 & 0.33 & \multirow{3}{*}{$\begin{array}{l}F=0.492 \\
p=0.741\end{array}$} \\
\hline & Post-test & 4.57 & 0.47 & 4.67 & 0.40 & 4.58 & 0.30 & \\
\hline & Follow up & 4.67 & 0.40 & 4.64 & 0.41 & 4.64 & 0.40 & \\
\hline \multirow{3}{*}{ Love of Learning } & Pre-test & 3.59 & 0.72 & 4.00 & 0.80 & 3.67 & 0.53 & \multirow{3}{*}{$\begin{array}{l}F=0.430 \\
p=0.786\end{array}$} \\
\hline & Post-test & 3.64 & 0.86 & 4.01 & 0.69 & 3.56 & 0.87 & \\
\hline & Follow up & 3.57 & 0.76 & 4.00 & 0.69 & 3.76 & 0.73 & \\
\hline & Pre-test & 4.75 & 0.32 & 4.60 & 0.40 & 4.60 & 0.39 & \\
\hline Gratitude & Post-test & 4.61 & 0.37 & 4.59 & 0.39 & 4.73 & 0.29 & $\begin{array}{l}F=1.203 \\
p=0.317\end{array}$ \\
\hline & Follow up & 4.65 & 0.31 & 4.57 & 0.46 & 4.76 & 0.31 & \\
\hline & Pre-test & 4.01 & 0.53 & 3.96 & 0.53 & 4.24 & 0.42 & \\
\hline Humility & Post-test & 4.15 & 0.55 & 4.07 & 0.53 & 4.29 & 0.39 & $\begin{array}{l}F=0.453 \\
p=0.770\end{array}$ \\
\hline & Follow up & 4.24 & 0.61 & 3.99 & 0.66 & 4.35 & 0.54 & \\
\hline & Pre-test & 4.08 & 1.02 & 3.96 & 0.69 & 4.04 & 0.90 & \\
\hline Humor & Post-test & 4.08 & 0.79 & 4.00 & 0.72 & 4.22 & 0.71 & $\begin{array}{l}F=0.204 \\
p=0.936\end{array}$ \\
\hline & Follow up & 4.12 & 0.92 & 4.05 & 0.69 & 4.16 & 0.72 & \\
\hline & Pre-test & 4.67 & 0.40 & 4.47 & 0.50 & 4.44 & 0.40 & \\
\hline Fairness & Post-test & 4.53 & 0.44 & 4.40 & 0.51 & 4.45 & 0.36 & $\begin{array}{l}F=0.520 \\
p=0.721\end{array}$ \\
\hline & Follow up & 4.53 & 0.40 & 4.45 & 0.55 & 4.51 & 0.33 & \\
\hline & Pre-test & 4.28 & 0.54 & 4.05 & 0.82 & 4.36 & 0.50 & \\
\hline Social Intelligence & Post-test & 4.31 & 0.51 & 3.97 & 0.72 & 4.27 & 0.40 & $\begin{array}{l}F=0.189 \\
p=0.909\end{array}$ \\
\hline & Follow up & 4.37 & 0.53 & 4.11 & 0.78 & 4.35 & 0.52 & \\
\hline & Pre-test & 4.31 & 0.48 & 3.96 & 0.87 & 4.11 & 0.52 & \\
\hline Leadership & Post-test & 4.20 & 0.61 & 4.07 & 0.68 & 4.25 & 0.53 & $\begin{aligned} F & =0.835 \\
p & =0.507\end{aligned}$ \\
\hline & Follow up & 4.32 & 0.53 & 4.19 & 0.78 & 4.15 & 0.46 & \\
\hline & Pre-test & 4.21 & 0.55 & 4.33 & 0.66 & 4.25 & 0.52 & \\
\hline Forgiveness & Post-test & 4.33 & 0.48 & 4.23 & 0.63 & 4.49 & 0.39 & $\begin{array}{l}F=1.225 \\
p=0.307\end{array}$ \\
\hline & Follow up & 4.39 & 0.54 & 4.28 & 0.71 & 4.36 & 0.41 & \\
\hline & Pre-test & 4.33 & 0.37 & 4.04 & 0.73 & 4.56 & 0.22 & \\
\hline Persistence & Post-test & 4.24 & 0.31 & 3.99 & 0.73 & 4.35 & 0.39 & $\begin{array}{l}F=0.912 \\
p=0.461\end{array}$ \\
\hline & Follow up & 4.25 & 0.60 & 4.21 & 0.78 & 4.51 & 0.39 & \\
\hline
\end{tabular}


Table 2

Cont.

\begin{tabular}{|c|c|c|c|c|c|c|c|c|}
\hline \multirow{3}{*}{ Character strengths } & \multirow{3}{*}{ Measure } & \multicolumn{6}{|c|}{ Group } & \multirow{3}{*}{ ANOVA $^{a}$} \\
\hline & & \multicolumn{2}{|c|}{ Experimental } & \multicolumn{2}{|c|}{ Active control } & \multicolumn{2}{|c|}{ Control } & \\
\hline & & $\mathbf{M}$ & SD & $\mathbf{M}$ & SD & $\mathbf{M}$ & SD & \\
\hline \multirow{3}{*}{ Perspective } & Pre-test & 4.01 & 0.59 & 3.67 & 0.55 & 3.98 & 0.66 & \multirow{3}{*}{$\begin{array}{l}F=0.303 \\
p=0.848\end{array}$} \\
\hline & Post-test & 3.95 & 0.66 & 3.77 & 0.53 & 3.87 & 0.60 & \\
\hline & Follow up & 4.07 & 0.67 & 3.85 & 0.65 & 3.98 & 0.86 & \\
\hline \multirow{3}{*}{ Prudence } & Pre-test & 4.39 & 0.62 & 3.89 & 0.68 & 4.35 & 0.46 & \multirow{3}{*}{$\begin{array}{l}F=0.828 \\
p=0.512\end{array}$} \\
\hline & Post-test & 4.49 & 0.43 & 3.96 & 0.68 & 4.31 & 0.42 & \\
\hline & Follow up & 4.44 & 0.39 & 4.16 & 0.85 & 4.45 & 0.43 & \\
\hline \multirow{3}{*}{ Zest } & Pre-test & 4.55 & 0.38 & 4.23 & 0.80 & 4.22 & 0.64 & \multirow{3}{*}{$\begin{array}{l}F=1.181 \\
p=0.326\end{array}$} \\
\hline & Post-test & 4.40 & 0.50 & 4.23 & 0.67 & 4.40 & 0.54 & \\
\hline & Follow up & 4.56 & 0.41 & 4.21 & 0.70 & 4.42 & 0.56 & \\
\hline
\end{tabular}

Table 3

Differences in Means and Standard Deviations in Pre-test, Post-test and Follow up for Psychological Well Being, Life Satisfaction and Depressive Symptoms by Group.

\begin{tabular}{|c|c|c|c|c|c|c|c|c|}
\hline \multirow{3}{*}{ Variable } & \multirow{3}{*}{ Measure } & \multicolumn{6}{|c|}{ Group } & \multirow{3}{*}{ ANOVA } \\
\hline & & \multicolumn{2}{|c|}{ Experimental } & \multicolumn{2}{|c|}{ Active Control } & \multicolumn{2}{|c|}{ Control } & \\
\hline & & $M$ & $D P$ & $M$ & $D P$ & M & $D P$ & \\
\hline \multirow{3}{*}{$\begin{array}{l}\text { Psychological Well } \\
\text { Being - Total }\end{array}$} & Pre-test & 9.87 & 1.60 & 10.07 & 1.94 & 9.82 & 1.08 & \multirow{3}{*}{$\begin{array}{l}F=0.942 \\
p=0.445\end{array}$} \\
\hline & Post-test & 12.20 & 3.10 & 11.13 & 3.54 & 12.91 & 2.47 & \\
\hline & Follow up & 12.60 & 3.92 & 12.73 & 3.10 & 13.27 & 3.07 & \\
\hline \multirow{3}{*}{$\begin{array}{l}\text { Psychological Well } \\
\text { Being - Agitation }\end{array}$} & Pre-test & 4.33 & 1.29 & 4.47 & 1.51 & 4.45 & 1.13 & \multirow{3}{*}{$\begin{array}{l}F=1.394 \\
p=0.244\end{array}$} \\
\hline & Post-test & 4.60 & 1.35 & 4.33 & 1.80 & 4.64 & 0.81 & \\
\hline & Follow up & 4.33 & 1.63 & 4.00 & 1.51 & 4.73 & 0.79 & \\
\hline \multirow{3}{*}{$\begin{array}{l}\text { Psychological Well } \\
\text { Being - Attitude } \\
\text { Toward Own Aging }\end{array}$} & Pre-test & 2.27 & 0.80 & 2.20 & 0.56 & 2.36 & 0.67 & \multirow{3}{*}{$\begin{array}{l}F=1.180 \\
p=0.326\end{array}$} \\
\hline & Post-test & 3.33 & 1.35 & 2.53 & 1.41 & 3.55 & 1.04 & \\
\hline & Follow up & 3.33 & 1.59 & 3.60 & 1.45 & 3.55 & 1.37 & \\
\hline \multirow{3}{*}{$\begin{array}{l}\text { Psychological Well } \\
\text { Being - Lonely } \\
\text { Dissatisfaction }\end{array}$} & Pre-test & 3.27 & 0.96 & 3.40 & 0.99 & 3.00 & 0.77 & \multirow{3}{*}{$\begin{array}{l}F=0.512 \\
p=0.727\end{array}$} \\
\hline & Post-test & 4.27 & 1.49 & 4.27 & 1.33 & 4.73 & 1.42 & \\
\hline & Follow up & 4.93 & 1.44 & 5.13 & 1.06 & 5.00 & 1.73 & \\
\hline \multirow{3}{*}{ Life Satisfaction } & Pre-test & 29.60 & 4.44 & 27.80 & 5.33 & 32.00 & 2.45 & \multirow{3}{*}{$\begin{array}{l}F=1.088 \\
p=0.370\end{array}$} \\
\hline & Post-test & 29.47 & 4.41 & 27.80 & 4.35 & 32.29 & 1.60 & \\
\hline & Follow up & 27.73 & 6.32 & 28.47 & 4.52 & 30.00 & 5.31 & \\
\hline \multirow{3}{*}{ Depressive symptoms } & Pre-test & 2.60 & 2.16 & 2.13 & 2.36 & 2.18 & 2.82 & \multirow{3}{*}{$\begin{array}{l}F=2.910 \\
p<0.05^{*}\end{array}$} \\
\hline & Post-test & 1.73 & 1.33 & 1.73 & 1.91 & 2.36 & 3.56 & \\
\hline & Follow up & 2.93 & 2.37 & 1.80 & 2.27 & 1.82 & 3.37 & \\
\hline
\end{tabular}

Note. ${ }^{\mathrm{a}} \mathrm{gl}=4 . *$ Statistically significant result.

\section{DISCUSSION}

In general, the results obtained in this investigation did not corroborate Hypotheses 1 and 2, since the intervention did not increase the CS, PWB and LS of older adults of the community. However, considering the control groups, the hypothesis was corroborated, that is, participating in other group activities that did not have CS as a focus (active control) or not attending any group activity (control group) does not promote CS, PWB or LS of these elderly. It should be clarified, however, that, in the case of the active control group, it was not possible to access the participation frequency of the person in the activities, which represents a limitation of this study. 
Regarding the CS, it is necessary to consider that the scores remained stable in the three groups and in the three assessment moments carried out over approximately ten months, which supports the understanding of CS's as stable traits. For McAdams and Pals (2006), genetically determined traits evolve into adult traits through a long process that involves complex influences between environment and disposition. However, the authors emphasize that the environmental influence tends to be modest and subtle. Furthermore, about character and virtues, for centuries some theorists (e.g., Aristotle and other philosophers) have already stated that their development is the product of habitual action and not just "thinking or talking" about them (Park \& Peterson, 2009). It is possible, therefore, that positive interventions drive the process, but it is only through sustained practice that changes can happen and be maintained (Park \& Peterson, 2009; Peterson \& Seligman, 2004).

Investigations by Flood and Scharer (2006), Ho et al. (2014), Oliveira (2010) and Ramírez et al. (2014) are examples of interventions with the elderly that aimed to promote one or some CS's. Oliveira's research (2010) was successful in promoting Hope, Ramírez et al. (2014) fostered Gratitude and Forgiveness and Ho et al. (2014) also promoted Gratitude. Flood and Scharer (2006) did not find any significant improvement in Creativity.

In general, promoting positive traits, such as CS, is not considered a simple or easy process (Peterson \& Seligman, 2004). With older adults it is possible that it will be even more complex, as personality traits tend to remain stable over the years (McCrae \& Costa Jr., 1994).

Another challenge of positive interventions, enunciated by Peterson and Seligman (2004), concerns those that aim, like this study, to promote happiness and/or its cognates. According to the authors, most of the time, a great number of people are already satisfied with their lives and, therefore, there could be a ceiling effect for variables related to happiness. This might be one of the reasons why elevations in the PWB and LS levels of Educafi participants were not obtained, since the scores of these two variables were already high in the pre-test.

Regarding the total PWB score, it was observed that the lowest average (9.87; amplitude $0-17$ ) presented by the elderly who participated in the intervention already indicated an intermediate level of this variable (Freitas et al., 2016a). Even so, both the total score and the two factors scores increased from the pre-test to the follow up, nevertheless, they are not statistically significant.

Educafi participants' LS also had a high average initial score (29.6; range 5-35). In the study by Gouveia et al. (2005), for example, the sample had an average score of $23.5(\mathrm{SD}=6.77)$, with people between 60 and 69 years old having an average score of 25.9 and individuals aged 70 or over, 29.0. The results demonstrate how satisfied older adults can be with their lives.
The ceiling effect was observed in this investigation not only for the two cognate variables of happiness, but also for CS. Among the elderly who participated in the intervention, the mean of the least endorsed strength was 3.76 (range 0-5). In addition, 20 of the $24 \mathrm{CS}$ 's had a score equal or greater than four points.

Another aspect that may explain the non-increase in the PWB and LS levels of the participants refers to the intensity of the relationship between CS and positive constructs. The 11 CS's that significantly correlated with the PWB of the elderly had weak magnitudes (Freitas, 2019). Similar results have been obtained in research with adults that analyzed subjective well-being (Littman-Ovadia \&Lavy, 2012). Therefore, it is suggested that CS-based interventions that aim to promote PWB of the elderly focus on the 11 CS's that correlated with the construct and include people with different levels (low, medium and high) of PWB in the sample so that their effectiveness can actually be tested.

When the objective is to promote LS, it is recommended that interventions based on CS focus on the five CS's that correlate most strongly with this variable: Gratitude; Hope; Zest; Curiosity; and Love (Niemiec, 2017). Proyer, Ruch and Buschor (2013) found an increase in the LS scores of participants who composed an intervention focused on four of these five CS's - Gratitude, Hope, Zest, Curiosity - and Humor.

In the group that participated of the intervention focusing on five CS's and showing low correlations with LS, there was no improvement of this variable. It should be noted that the study by Proyer et al. (2013) had a primarily adult sample $(M=41.20 ; S D=13.08 ; 18-76$ years old $)$. Thus, research is also needed to investigate which CS correlates most strongly with the elderly LS.

Finally, to understand these results, it is necessary to consider the frequency of the participants at the meetings and the action plans. Regarding the first item, it is important to mention that four elderly women had frequency lower than $75 \%$ at Educafi and only one completed $100 \%$ of the intervention.

Regarding the action plans, it was observed that they were not always made, they were partially made or were quickly made before the beginning of the meeting. Action plans play a central role in CBT, as they contribute to the understanding of the content worked and to its training in real daily situations, allowing information to remain "alive" throughout the week (Neufeld et al., 2017). Thus, not practicing the action plans as requested may have contributed to the results.

Despite this, other positive interventions that had CS not as a focus, but as one of the topics addressed, found improvements in PWB (Ribeiro, 2011), in LS (CuadraPeralta et al., 2012; Ho et al., 2014; Kashaniyan\&Koolaee, 2015) and happiness (Ho et al., 2014; Jiménez et al., 2016) of the elderly. Therefore, it is possible that there are other variables mediating the causal relationship between positive 
intervention and LS and well-being increases, which were not addressed in Educafi. Pleasant activities can be an example, as the theme was directly addressed in the interventions of Ribeiro (2011) and Cuadra-Peralta et al. (2012) and it was not at Educafi.

Although Educafi did not contribute to raise the levels of the positive constructs analyzed, it was effective, to a limited extent, in reducing depressive symptoms. This result corroborates those presented in literature with adults (Bolier et al., 2013; Schutte \&Malouff, 2018) and elderly (Cuadra-Peralta et al., 2012; Ho et al., 2014; Ribeiro, 2011).

It should be noted that the tendency to decrease depressive symptoms can be attributed more to Educafi than to the group intervention modality or to the time effect. It is important to restate that a comparison with an active control group was used to control the effects of being in a group, regardless of the content of the intervention. In this group and in the control group, there were no statistically significant changes in depressive symptoms, in contrast to the results of the Educafi participants.

Despite the effectiveness in the initial reduction of depressive symptoms, the GDS-15 scores returned to baseline six months after the end of Educafi. Therefore, Hypothesis 3 was only partially confirmed. Thus, the importance of follow-up assessments is corroborated, as they allow researchers to analyze the effectiveness of an intervention over time. The studies by Ribeiro (2011), Cuadra-Peralta et al. (2012) and Ho et al. (2014), for example, despite the impressive results in promoting positive aspects and reducing depressive symptoms, did not perform a follow up test.

As for the reduction and return to the initial level of depressive symptoms, it should also be considered that the Educafi participants did not have symptoms that were indicative of depression (score greater than six points on the GDS-15) in the pre-test. Since the level of depression acts as a mediator for positive interventions, so that depressed individuals benefit more from these interventions (Sin \& Lyubomirsky, 2009), it is suggested that future positive interventions include elderly people with different degrees of depression.

In general, when the objective is to reduce depressive symptoms in the elderly, Educafi constitutes an alternative intervention to the traditional GCBT, which focus on the "negative" (Freitas et al., 2016b). However, for this increase to be maintained over time and other objectives be achieved, such as raising the PWB and LS, it is necessary to consider at least two aspects: the sample; and the structure of Educafi.

Regarding the sample, other studies that include older adults with low levels of PWB and LS and with moderate and/or severe depressive symptom are recommended. Concerning the structure of Educafi, it is suggested that future research focus, instead of the $24 \mathrm{CS}$, the five that are associated with both higher levels of PWB and less depressive symptoms in the elderly, that is, Hope, Forgiveness, Zest, Curiosity and Love (Freitas, 2019).

In addition, it is recommended that research include "encouragement sessions", for example, one, three and six months after the end of Educafi. This kind of strategy contributes to strengthen the learning process obtained during the intervention (Beck, 1997). In the case of Educafi, these moments can be used to assess whether cognitive distortions related to the CS have been reactivated and, if so, to restructure them, to analyze what has limited their experience and what has contributed to the practice of the CS. Also, in the encouragement sessions, the elderly should be alerted about the importance of regular practice of the $\mathrm{CS}$, incorporating them in their daily lives so that habits can be developed.

One last aspect that needs to be mentioned is the promotion of CS's in old age. Further studies exclusively with the elderly are needed to test whether this is possible, whether it is feasible for all CS's and under what conditions. Positive results for the promotion of CS's and virtues have been found in literature on Education for Character with young people (Rich, 2009). However, as in positive interventions and GCBT, studies on character education with the elderly are scarce.

Finally, despite the contributions of this investigation, it is worth mentioning its limitations. Regarding the instrument used to assess CS, the VIA-IS-120, it is known that it has satisfactory psychometric properties, but they were not tested exclusively for the Brazilian context and were analyzed with samples composed mainly of adults. Thus, it is necessary for their properties to be verified for Brazilian participants in general, including, of course, the elderly.

Another important limitation of this study refers to the sample used. In the three groups, they were composed in a non-probabilistic way, obtained by convenience, and are relatively small and mostly female. It is suggested that future research also uses probabilistic samples, which are more representative and randomized. 


\section{REFERENCES}

Albuquerque, F. J. B., Rodrigues, C. F. F., Gouveia, C. N. N. A., Martins, C. R., \& Neves, M. T. S. (2007, Julho 25-28). Validação de uma escala de satisfação com a vida para idosos de baixa renda na Paraíba [Sessão de poster]. III Congresso Brasileiro de Avaliação Psicológica e XII Conferência Internacional de Avaliação Psicológica: Formas e Contextos, João Pessoa, PB, Brasil. http://www.ibapnet.org. br/congresso2007/LivroPaineis2007.pdf

Almeida, O. P., \& Almeida, S. A. (1999). Confiabilidade da versão brasileira da Escala de Depressão em Geriatria (GDS) versão reduzida. Arquivos de Neuropsiquiatria, 57(2-B), 421-426. https://doi.org/10.1590/S0004-282X1999000300013

Baumann, D., Ruch, W., Margelisch, K., Gander, F., \& Wagner, L. (2020). Character strengths and life satisfaction in later life: An analysis of different living conditions. Applied Research in Quality of Life, 15, 329-347. https://doi.org/10.1007/s11482018-9689-x

Beck, J. S. (1997). Terapia cognitiva: Teoria e prática. Artmed.

Bertolucci, P. H., Brucki, S., Campacci, S. R., \& Juliano, Y. (1994). O Mini-Exame do Estado Mental em uma população geral: impacto da escolaridade. Arquivos de Neuropsiquiatria, 52(1), 01-07. https://www.scielo.br/j/anp/i/1994.v52n1/

Bolier, L., Haverman, M., Westerhof, G., Riper, H., Smit, F., \&Bohlmeijer, E. (2013). Positive psychology interventions: A meta-analysis of randomized controlled studies. $B M C$ Public Health, 13(119), 1-20. https://doi.org/10.1186/14712458-13-119

Brucki, S. M. D., Nitrini, R., Caramelli, P., Bertolucci, P. H. F., \& Okamoto, I. H. (2003). Sugestões para o uso do Mini-Exame do Estado Mental no Brasil, Arquivos de Neuropsiquiatria, 61(3B), 777-781. http://dx.doi.org/10.1590/ S0004-282X2003000500014

Cuadra-Peralta, A., Veloso-Besio, C., Puddu-Gallardo, G., SalgadoGarcía, P., \& Peralta-Montecinos, J. (2012). Impacto de un programa de Psicología Positiva en sintomatología depresiva y satisfaccion vital en adultos mayores. Psicologia: Reflexão e Crítica, 25(4), 644-652. https://doi.org/10.1590/S010279722012000400003

Flood, M., \&Scharer, K. (2006). Creativity enhancement: Possibilities for successful aging. Issues in Mental Health Nursing, 27, 939-959. https://doi.org/10.1080/01612840600899832

Freitas, E. R. (2019). Forças do caráter de idosos: Conhecer e intervir [Tese de Doutorado, Universidade Federal de Juiz de Fora]. Biblioteca Digital Brasileira de Teses e Dissertações. https://repositorio.ufjf.br/jspui/handle/ufjf/10102

Freitas, E. R., Barbosa, A. J. G., Reis, G. A., \& Gomes, L. B. (2016a). Bem-estar psicológico na clínica com idosos: Avaliação e intervenção. In E. R. Freitas, A. J. G. Barbosa \&C. B. Neufeld (Orgs.), Terapias Cognitivo-Comportamentais com Idosos (pp. 119-135). Sinopsys.

Freitas, E. R., Barbosa, A. J. G., \&Neufeld, C. B. (2016b). Educação para o caráter: Proposta de intervenção em grupo com idosos para promover forças e virtudes. In E. R. Freitas, A. J. G. Barbosa \& C. B. Neufeld (Orgs.), Terapias CognitivoComportamentais com Idosos (pp. 329-351). Sinopsys.

Ghielen, S. T. S., Woerkom, M. V., \& Meyers, M. C. (2018). Promoting positive outcomes through strengths interventions: A literature review. The Journal of Positive Psychology, 13(6), 573-585. https://doi.org/10.1080/17439760.2017.1365164

Gouveia, V. V., Barbosa, G. A., Andrade, E. D. O., \& Carneiro, M. B. (2005). Medindo a satisfação com a vida dos médicos no Brasil. Jornal Brasileiro de Psiquiatria, 54(4), 298-305.

Hill, R. D., \& Smith, D. J. (2015). Positive aging: At the crossroads of positive psychology and geriatric medicine. In P. A. Lichtenberg, B. T. Mast, B. D. Carpenter, \& J.
Loebach Wetherell (Eds.), APA Handbooks in Psychology. APA Handbook of Clinical Geropsychology(vol. 1, pp. 301-329). American Psychological Association.https://doi. org/10.1037/14458-013

Ho, H. C., Yeung, D. Y., \& Kwok, S. Y. (2014). Development and evaluation of the positive psychology intervention for older adults. The Journalof Positive Psychology, 9(3), 187-197. https://doi.org/10.1080/17439760.2014.888577

Instituto Brasileiro de Geografia e Estatística (2018, 26 de abril). Número de idosos cresce $18 \%$ em 5 anos e ultrapassa 30 milhões em 2017. https://agenciadenoticias.ibge.gov.br/ agencia-noticias/2012-agencia-de-noticias/noticias/20980numero-de-idosos-cresce-18-em-5-anos-e-ultrapassa-30milhoes-em-2017

Jiménez, M. G., Izal, M., \& Montorio, I. (2016). Programa para la mejora del bienestar de las personas mayores. Estudio piloto basado en la psicología positiva. Suma psicológica, 23(1), 5159. https://doi.org/10.1016/j.sumpsi.2016.03.001

Kashaniyan, F., \&Koolaee, A. K. (2015). Effectiveness of positive psychology group interventions on meaning of life and life satisfaction among older adults. Elderly Health Journal, 1(2), 68-74. http://ehj.ssu.ac.ir/article-1-44-en.html

Killen, A., \& Macaskill, A. (2020). Positive ageing: To what extent can current models of wellbeing categorise the life events perceived as positive by older adults? International Journal of Applied Positive Psychology, 5, 99-119. https://doi. org/10.1007/s41042-020-00028-6

Lawton, M. P. (1991). A multidimensional view of quality of life in frail elders. In R. P. Abeles (Ed.), The concept and measurement of quality of life in the frail elderly (pp. 3-27). Academic Press.

Littman-Ovadia, H. (2015). Brief report: Short form of the VIA Inventory of Strengths-construction and initial tests of reliability and validity. International Journal of Humanities Social Sciences and Education (IJHSSE), 2(4), 229-237. https://www.arcjournals.org/pdfs/ijhsse/v2-i4/27.pdf

Littman-Ovadia, H., \&Lavy, S. (2012). Character strengths in Israel: Hebrew adaptation of the VIA Inventory of Strengths. European Journal of Psychological Assessment, 28(1), 41-50. https://doi.org/10.1027/1015-5759/a000089

Littman-Ovadia, H., \&Lavy, S. (2015). Going the extra mile: Perseverance as a key character strength at work. Journal of Career Assessment, 24(2), 240-252. https://doi. org/10.1177/1069072715580322

Lourenço, R. A., \& Veras, R. P. (2006). Mini-Exame do Estado Mental: Características psicométricas em idosos ambulatoriais. Revista de Saúde Pública, 40(4), 712-719. https://www.scielosp.org/pdf/rsp/2006.v40n4/712-719/pt

Lourenço, R. A., Veras, R. P., \& Ribeiro, P. C. C. (2008). Confiabilidade teste-reteste do Mini-Exame do Estado Mental em uma população idosa assistida em uma unidade ambulatorial de saúde. Revista Brasileira de Geriatria \& Gerontologia, 11(1), 7-16. http://www.redalyc.org/articulo. oa? id $=403838777002$

McAdams, D. P., \& Pals, J. L. (2006). A new Big Five: Fundamental principles for an integrative science of personality. American Psychologist, 61(3), 204-217. https://doi.org/10.1037/0003066X.61.3.204

McCrae, R. R., \& Costa Jr, P. T. (1994). The stability of personality: Observations and evaluations. Current Directions in Psychological Science, 3(6), 173-175. https://doi. org/10.1111/1467-8721.ep10770693

Neufeld, C. B., Maltoni, J., Ivatiuk, A. L., \&Rangé, B. P. (2017). Aspectos técnicos e o processo em TCCG. In C. B. Neufeld\& B. P. Rangé (Orgs.), Terapia cognitivo-comportamental em grupos (pp. 33-54). Artmed. 
Niemiec, R. M. (2017). Character strengths interventions: A field guide for practitioners. Hogrefe.

Oliveira, J. A. G. (2010). Terapia de esperança: Uma intervenção grupal que visa promover a esperança de idosos institucionalizados [Dissertação de Mestrado, Universidade de Coimbra]. Repositório Científico da UC.http://hdl.handle. net/10316/15341

World Health Organization. (2015). World report on ageing and health. https://www.who.int/ageing/events/world-report-2015launch/en/

Park, N., \& Peterson, C. (2009). Character strengths: Research and practice. Journal of College \& Character, 10(4), 1-11. https:// doi.org/10.2202/1940-1639.1042

Peterson, C., \& Seligman, M. E. P. (2004). Character strengths and virtues: A handbook and classification. American Psychological Association.

Proyer, R. T., Gander, F., Wellenzohn, S., \& Ruch, W. (2014). Positive psychology interventions in people aged 50-79 years: Long-term effects of placebo-controlled online interventions on well-being and depression. Aging \& Mental Health, 18(8), 997-1005. https://doi.org/10.1080/13607863.2014.899978

Proyer, R. T., Ruch, W., \&Buschor, C. (2013). Testing StrengthsBased Interventions: A preliminary study on the effectiveness of a program targeting curiosity, gratitude, hope, humor, and zest for enhancing life satisfaction. Journal of Happiness Studies, 14(1), 275-292. https://doi.org/10.1007/s10902-0129331-9

Ramírez, E., Ortega, A. R., Chamorro, A., \&Colmenero, J. M. (2014). A program of positive intervention in the elderly: Memories, gratitude and forgiveness. Aging \& Mental
Health, 18(4), 463-470. https://doi.org/10.1080/13607863.2 013.856858

Ribeiro, L. I. O. (2011). Positividade: Intervenção em grupo com pessoas idosas [Dissertação de Mestrado, Universidade de Coimbra]. Repositório Científico da UC.http://hdl.handle. net/10316/17721

Rich, G. J. (2009). Character education. In S. J. Lopez (Ed.), The encyclopedia of positive psychology (vol. 2, pp. 129-135). Blackwell Publishing.

Schutte, N. S., \&Malouff, J. M. (2018). The impact of signature character strengths interventions: A meta-analysis. Journal of Happiness Studies, 20, 1179-1196. https://doi.org/10.1007/ s10902-018-9990-2

Scoralick-Lempke, N. N., \& Barbosa, A. J. G. (2012). Educação e envelhecimento: Contribuições da perspectiva LifeSpan. Estudos de Psicologia, 29, 647-655. https://www. redalyc.org/pdf/3953/395335581001.pdf

Seibel, B. L., DeSousa, D., \& Koller, S. H. (2015). Adaptação brasileira e estrutura fatorial da Escala 240-item VIA InventoryofStrengths. Psico-USF, 20(3), 371-383. http:// dx.doi.org/10.1590/1413-82712015200301

Seligman, M. E. P., \&Csikszentmihalyi, M. (2000). Positive psychology: An introduction. American Psychologist, 55(1), 5-14. http://doi 10.1037/0003-066X.55.1.5

Sin, N. L., \&Lyubomirsky, S. (2009). Enhancing well-being and alleviating depressive symptoms with positive psychology interventions: A practice-friendly meta-analysis. Journal of Clinical Psychology, 65(5), 467-487. https://doi.org/10.1002/ jclp.20593 